\title{
Pemodelan Arima Harga Jagung Internasional
}

\author{
Arima Model for International Corn Price \\ Devi Oktiani \\ Balai Riset dan Standardisasi Industri Bandar Lampung \\ Jl. By Pass Soekarno Hatta KM.1 Rajabasa Bandar Lampung , 35142, Indonesia \\ e-mail : divya_de_vi@yahoo.com
}

\begin{abstract}
Abstrak
Penelitian ini bertujuan untuk memberikan suatu model yang dapat memprediksi harga jagung pada pasar internasional. Manfaat dari adanya model ini adalah dapat digunakan oleh industri yang menggunakan bahan baku jagung, khususnya jagung impor sebagai bahan baku industri, misalnya industri pakan ternak. Dilakukan peramalan model menggunakan model autoregerssive integrated moving average (ARIMA), telah dilakukan identifikasi beberapa model ARIMA yang dapat diterapkan, dan telah dipilih bahwa model ARIMA yang paling sesuai adalah ARIMA(3,1,3). Data yang digunakan adalah data sekunder dalam bentuk data deret waktu. Model yang didapatkan dapat digunakan untuk memprediksi harga jagung di masa datang, sehingga dapat bermanfaat bagi perusahaan yang menggunakan bahan baku jagung. Peramalan harga jagung tahun 2020 dan 2021 menunjukkan kecenderungan penurunan harga, yang mana hal tersebut disebabkan oleh data kecenderungan penurunan harga pada awal 2020 sebagai akibat pandemi COVID-19.
\end{abstract}

Kata kunci: jagung, harga, ARIMA, COVID-19.

\begin{abstract}
The objective of this study is to provide a model for corn price prediction in international market. The benefit of this model is that it can be used by industries that use corn as raw material, especially imported corn as raw material, for example is the animal feed industry. The model is an auto regressive integrated moving average (ARIMA) model, this research identified several ARIMA models that can be applied, and choose the most appropriate ARIMA model, it is ARIMA $(3,1,3)$. This research use time series secondary data. This model can be used for forecasting the future corn price, which is beneficial for industries which use corn as raw material. The forecasting analysis on the years of 2020 and 2021 indicates lower price trend, which is caused by the tendency of lower prices during the early 2020 as an impact of COVID-19 pandemic.
\end{abstract}

Keywords: corn, price, ARIMA, COVID -19.

\section{Pendahuluan}

Jagung merupakan bahan pangan yang dapat dikonsumsi langsung atau digunakan sebagai bahan pangan produk olahan lain. Jagung juga banyak digunakan sebagai bahan utama pakan ternak. Di Indonesia, pemanfaatan jagung sebagai pakan ternak lebih besar (58\%) daripada sebagai bahan pangan (30\%) (Pannikai, et.all, 2017). Pemanfaatan jagung sebagai pakan ternak dimulai sejak tahun 1970 an (Purwasih,et. all, 2017). Jenis pakan ternak yang menggunakan bahan jagung adalah jenis pakan ternak unggas (Oktiani, 2016). Berdasar data dari Kementerian Perdagangan Indonesia (2018), pemanfaatan jagung dalam bentuk jagung pipilan kering pada tahun $2018 \mathrm{di}$ Indonesia adalah untuk diolah lebih lanjut sebagai bahan pakan ternak pada industri pakan ternak sebesar 7,76 juta ton, selain itu juga digunakan oleh peternak mandiri sebesar 2,52 juta ton, digunakan oleh industri benih $120 \mathrm{ribu}$ ton, dan digunakan oleh industri pangan sebesar 4,76 juta ton. Data tersebut menggambarkan bahwa pemanfaatan jagung dalam industri pakan ternak adalah sangat besar. Industri pakan ternak yang dimaksud adalah merupakan pabrik skala besar. Pabrik - pabrik tersebut selalu merencanakan secara detil sumber pasokan jagung dan memantau harga jagung.

Berdasar data dari Kementerian Pertanian Indonesia (2016) komposisi jagung sebagai pakan ternak dapat mencapai hingga $51.4 \%$, yang mana pakan ternak jenis unggas merupakan pakan ternak yang paling banyak komposisi jagungnya. Peningkatan jumlah kebutuhan jagung di Indonesia disebabkan oleh 
peningkatan jumlah penduduk (Susilo, 2012). Peningkatan jumlah penduduk menyebabkan peningkatan kebutuhan jagung sebagai bahan makanan maupun peningkatan jumlah ternak yang secara berantai menyebabkan peningkatan kebutuhan pakan ternak. Sehingga secara umum, peningkatan permintaan jagung di Indonesia disebabkan oleh peningkatan kebutuhan pada industri pakan ternak (Rahmah, et, all., 2017).

Pada pasar internasional, sejak tahun 2002, jagung banyak digunakan sebagai bahan pangan sumber energi, sehingga kebutuhan jagung di pasar internasional meningkat, melebihi gandum dan beras. Kebutuhan jagung di pasar internasional juga dipengaruhi oleh tingginya elastisitas kebutuhan (demand) untuk produk hewani khususnya hewan ternak, serta semakin tingginya konsumsi produk hewani di negara- Negara berkembang (Wright, 2011).

Produksi jagung internasional didominasi oleh Amerika Serikat, Cina, dan Brazil. Sedangkan Negara yang paling banyak mengekspor adalah Amerika Serikat, Brazil, dan Argentina. Cina memiliki karakteristik sebagai negara produsen dan konsumen jagung dalam jumlah yang seimbang, sehingga Cina dapat mandiri. Sedangkan Amerika Serikat meskipun merupakan negara produsen dan pengekspor jagung tebesar, namun komposisi konsumsi jagung di dalam negrinya cukup besar dan lebih besar daripada ekspornya, sehigga hal tersebut dapat menyebabkan Amerika Serikat sangat berpengaruh dalam penentuan harga jagung di pasar internasional (Bantacut, et. all, 2015). Secara umum, karaktristik pertanian jagung di Amerika Serikat adalah: merupakan makanan pokok di negara, dimanfaatkan untuk pakan ternak dan produksi etanol, tidak banyak variasi kebijakan, infrastruktur pendukungnya baik, memiliki pasar masa depan yang besar, dan informasi tentang pasar mudah didapatkan (Svanidze, 2019).

Menurut data Kementerian Pertanian Indonesia (2016) kuantitas jagung yang diperdagangkan di pasar internasional selalu meningkat dari tahun ke tahun.Daerah dengan luas lahan perkebunan jagung terluas di Indonesia adalah Jawa Timur (30,73\%), kemudian Jawa Tengah $(13,97 \%)$ dan Lampung $(8,49 \%)$. Di Propinsi Lampung terdapat enam perusahaan pakan ternak berskala internasional yang mengunakan bahan baku utama jagung. Perusahaan tersebut menggunakan bahan berupa jagung dari Lampung, karena jagung Lampung meiliki tekstur dan rasa yang spesifik dan sesuai digunakan sebagai bahan pakan ternak (Oktiani, 2016). Namun demikian, pasokan jagung lokal tersebut tidak cukup, sehingga perusahaan pakan ternak masih tetap perlu melakukan impor jagung dalam jumlah banyak, tabel 1 menunjukkan jumlah impor jagung yang dilakukan Indonesia.

Tabel 1. Impor Jagung Indonesia

\begin{tabular}{cc}
\hline Tahun & Jumlah Impor (Ton) \\
\hline 2012 & 1.692 .995 \\
2013 & 3.191 .045 \\
2014 & 3.253 .619 \\
2015 & 3.267 .694 \\
2016 & 1.139 .694 \\
2017 & 474.854 \\
\hline
\end{tabular}

Sumber Data: FAO,

http://www.fao.org/faostat/en/\#data/TP, 2020.

Jagung merupakan tanaman musiman, kondisi iklim di Indonesia menyebabkan jagung tidak dapat dipanen sepanjang hari. Panen jagung bergantung pada kondisi musim, sehingga terjadi fluktuasi harga antara saat musim panen dan saat musim pasokan berkurang (Susanti, et.all. 2017). Pada musim persediaan jagung lokal sedikit, harga jagung lokal dapat meningkat. Harga jagung pipilan di Indonesia pada Oktober 2018 adalah Rp. 7.677/Kg dan meningkat menjadi Rp. 7.940/ Kg pada bulan November 2018. Harga tersebut cukup tinggi jika dibandingkan dengan harga pada November 2017 yaitu Rp. 6.556/kg (Kementerian Perdagangan, 2018).

Perubahan harga jagung pada tingkat petani jagung relatif kecil, namun perubahan harga pada tingkat konsumen cukup besar hal ini disebabkan karena para pedagang atau pengumpul jagung menetukan marjin dan mengendalikan pasar (Susanti, et. all, 2017; Rahmi, et,all. 2012). Hal tersebut berdampak merugikan bagi petani jagung dan peternak ayam. Petani jagung sebagai produsen jagung dan juga peternak ayam sebagai pengguna pakan ternak berbahan jagung tidak diuntungkan dengan kondisi tersebut, karena mendapat keuntungan yang tetap kecil. Untuk dapat bersaing dengan produk impor maka diperlukan peningkatan produktifitas dan efisiensi harga (Setiawan, et.all. , 2017).

Korelasi yang kuat antara harga jagung dan harga produk hewan ternak juga terjadi di Amerika Serikat (Arcaz, 1979), yang mana Amerika Serikat merupakan salah satu Negara yang mengekspor jagung dan produk peternakan dalam jumlah besar di dunia, sehingga dapat berpengaruh pada Indonesia. Penelitan terdahulu menyebutkan bahwa harga jagung Amerika serikat memiliki pengaruh terhadap harga jagung di Cina, yang mana kedua 
Negara tersebut merupakan Negara yang berpengaruh pada perdagangan produk pertanian di dunia. Secara umum harga jagung ini menarik untuk dipelajari karena merupakan komoditi yang volatilitasnya tinggi, lebih tinggi dibanding beras dan gandum (Kornhern, et.all, 2013).

Kebutuhan jagung nasional lebih besar dari pada jumlah produksi jagung dalam negri, sehingga Indonesia masih harus mengimpor jagung (Firna, 2018). Kementerian Perdagangan (2018) menyebutkan bahwa Indonesia telah mengimpor 503.000 ton jagung, senilai US\$ 109.900.000 pada bulan Januari - Oktober 2018, jagung impor tersebut berasal dari Argentina dan Amerika Serikat. Melihat bahwa jumlah impor jagung sangat besar, maka pada penelitian ini dilakukan pemodelan harga jagung pada pasar internasional, diharapkan model tersebut dapat digunakan oleh pelaku industri dan juga pembuat kebijakan untuk memprediksikan harga jagung impor atau harga jagung di pasar internasional. Model dapat digunakan oleh perusahaan yang menggunakan jagung impor untuk memprediksi harga jagung di masa depan.

Model yang digunakan adalah model autoregrssive integrated moving average (ARIMA). Model ARIMA ini memprediksi nilai dependen variable dengan cara mengunakan data -data dependen variabel pada waktu atau masa - masa sebelumnya atau nilai masa lalu dependen variabel, tanpa menggunakan independen variabel lainnya. Model ini akurat digunakan untuk peramalan jangka pendek merupakan gabungan antara model autoregression dan moving average. Dalam hal ini maksud kata 'integrated' adalah kebalikan dari defernsiasi.

\section{Metode Penelitian}

Pemodelan menggunakan model ARIMA, data diolah menggunkan software Eviews 6. Model autoregressive (AR) order ke- $p$ dapat dituliskan sebagai berikut (Firdaus, 2011; dan Hyndman, et.all. ,2018),

$y t=c+\phi 1 y t-1+\phi 2 y t-2+. .+\phi p y t-p+\varepsilon t \ldots(1)$

Keterangan :

$y t=$ nilai variable y pada tahun ke-t.

$\oint=$ koefisien

$c=$ konstanta

$\varepsilon t=$ white noise atau residu.

Model Moving Average pada order ke- $q$ adalah sebagai berikut,

$y t=c+\varepsilon t+\theta 1 \varepsilon t-1+\theta 2 \varepsilon t-2++\theta q \varepsilon t-q \ldots$ (2)

Keterangan:

$y t=$ nilai variable y pada tahun ke-t. $\theta=$ koefisien

$c=$ konstanta

$\varepsilon t=$ white noise pada tahun ke-tatau residu.

Regresi dilakukan pada deret yang stasioner, jika belum stasioner maka harus dilakukan diferensiasi,

$y^{\prime} t=y t-y t-1 \quad \ldots(3)$

Keterangan :

$y^{\prime} t=$ diferensasi pertama atau selisih atau $1^{\text {st }}$ difference $y$ pada tahun ke- $t$.

Gabungan antara moving average dan autoregressive untuk deret terdiferensiasi $1^{\text {st }}$ difference secara lengkap model dapat dituliskan sebagai berikut [12-14],

$y^{\prime} t=c+\phi 1 y^{\prime} t-1+\ldots+\phi p y^{\prime} t-p+\theta 1 \varepsilon t-1+\ldots . .+\theta q \varepsilon t-$

$1+\varepsilon t \ldots(4)$

Keterangan:

$y^{\prime} t=$ deret yang terdiferensiasi,

Persamaan dapat terdiferensiasi lebih dari satu kali. dengan $\oint$ dan $\theta$ adalah koefisien.Model dituliskan sebagai ARIMA $(p, d, q)$, dengan $p$ adalah order autoregressive, $d$ adalah tingkat differensiasi, dan $q$ adalah order moving average.

Data yang digunakan adalah data harga jagung di pasar internasional deret waktu (time series) dengan menggunakan data yang berasal dari indexmundi (Indexmundi Maize Monthly Price - US Dollars per Metric Ton, 2019). Data merupakan data deret waktu (time series) setiap bulan dari bulan. Untuk menidentifikasi model digunakan data September 1989 hingga bulan September 2019. Sedangkan untuk forecasting digunakan data dari Januari 2019 hingga April 2020.

\section{Hasil Dan Pembahasan}

Harga jagung di pasar internasional (PRICE) menunjukkan kecenderuangan yang fluktuatif, Gambar 1 menunjukkan harga per bulan harga jagung dari bulan September 1989 hingga bulan September 2019 dalam satuan US\$/ton. Harga yang fluktuatif tersebut dapat menyebabkan industri yang menggunakan bahan baku jagung dalam jumlah banyak kesulitan untuk melakukan pembelian saat harga mengalami peningkatan. Adanya teknik pemodelan secara ekonometrik ini dapat mempermudah industri dalam memperkirakan harga jagung pada masa yang akan datang dan menentukan strategi serta melakukan perencanaan.

Grafik harga jagung (PRICE) menunjukkan bahwa data tidak stasionar, sehingga peramalan model secara ARIMA menggunakan data pada level PRICE tidak dapat dilakukan. Untuk mempertegas bahwa data tidak stasioner dilakukan analisis menggunakan 
ADF test dan didapatkan bahwa nilai statistik ADF test lebih besar daripada nilai kritisnya (Tabel 2).

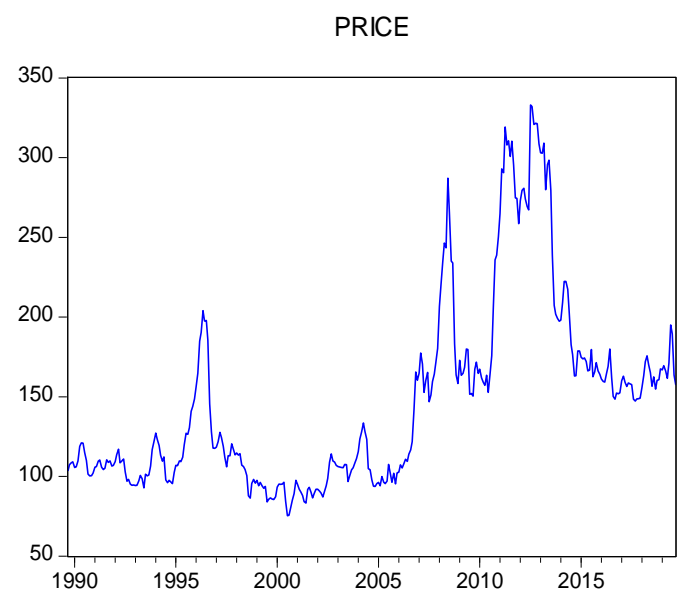

Gambar 1. Harga Jagung (US\$/ton), tahun 1990 -2019 (Sumber data: Indexmundi Maize (corn) Monthly Price, 2019)

Tabel 2. Uji ADF Test Harga Jagung (PRICE)

\begin{tabular}{ccc}
\hline Test critical value & t-statistik & Probabilitas \\
\hline ADF test statistik & -2.099663 & 0.2451 \\
$1 \%$ level & -3.448363 & \\
$5 \%$ level & -2.869374 & \\
$10 \%$ level & -2.571011 & \\
\hline
\end{tabular}

Keterangan :

Null hypothesis : PRICE has a unit root

Selanjutnya dilakukan diferensiasi 1 tingkat, Variabel pada diferensiasi 1 tingkat (1 ${ }^{\text {st }}$ difference) ini disebut sebagai D(PRICE). Uji stasionaritas pada turunan pertama menunjukkan bahwa data pada turunan pertama sudah stasioner, seperti terlihat pada grafik Gambar 2.

D(PRICE)

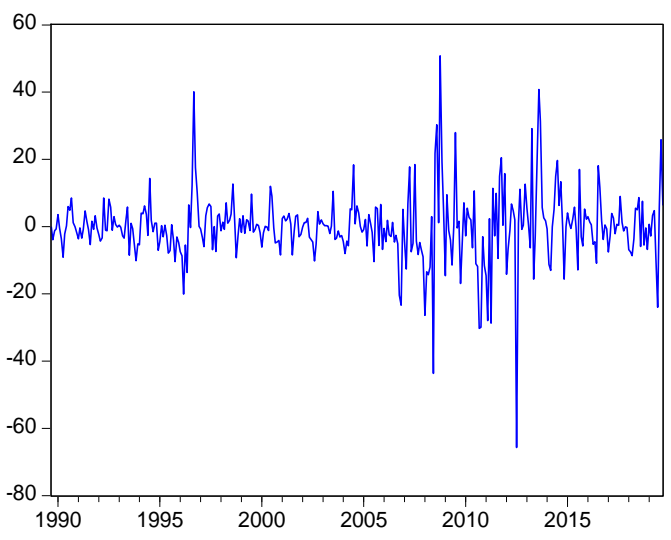

Gambar 2. $1^{\text {st }}$ difference harga jagung
Untuk mempertegas bahwa data D(PRICE) sudah stasioner, maka dilakukan uji unit root test yang meliputi Augmented Dickey Fuller (ADF) test, Dickey Fuller (DF) test, dan Phillip Pearson (PP) test . Tabel 2, 3, dan 4 menunjukkan uji unit root tersebut, dan dapat dilihat bahwa probabilitasnya 0,0000, yang berarti data sudah stasioner, sehingga untuk selanjutnya dilakukan pemodelan ARIMA pada $1^{\text {st }}$ difference.

Tabel 3. Uji ADF Test D(PRICE)

\begin{tabular}{ccc}
\hline Test critical value & t-statistik & Probabilitas \\
\hline ADF test statistik & -15.02723 & 0.0000 \\
1\% level & -3.448363 & \\
5\% level & -2.869374 & \\
$10 \%$ level & -2.571011 & \\
\hline
\end{tabular}

Keterangan :

Null hypothesis : D(PRICE) has a unit root

Tabel 4. Uji DF Test D(PRICE)

\begin{tabular}{cc}
\hline Test critical value & t-statistik \\
\hline Elliott-Rothenberg-Stock & \\
DF-GLS test statistic & -15.02723 \\
$1 \%$ level & -2.571419 \\
$5 \%$ level & -1.941709 \\
$10 \%$ level & -1.616108 \\
\hline
\end{tabular}

Keterangan :

Null hypothesis : D(PRICE) has a unit root

Tabel 5. Uji Phillip Pearson Test D(PRICE)

Test critical t-statistik Probabilitas value

\begin{tabular}{ccc} 
Phillip & & 0.0000 \\
Pearson test & -15.00935 & \\
$1 \%$ level & -3.448363 & \\
$5 \%$ level & -2.869374 & \\
$10 \%$ level & -2.571011 & \\
\hline
\end{tabular}

Keterangan :

Null hypothesis : D(PRICE) has a unit root

Dengan dipilihnya pemodelan ARIMA pada $1^{\text {st }}$ difference, maka bentuk ARIMA adalah $\operatorname{ARIMA}(p, 1, q)$. Terdapat beberapa alternatif nilai p dan q. Memperhatikan bentuk korelogram pada Tabel 5 maka dapat diduga bahwa nilai ordo auto regressive (p) adalah 1 atau 3 , karena terlihat patahnya korelogram pada nilai 1 atau 3. Sedangkan ordo moving average (q) adalah pada nilai 1 atau 3. Angka probabilitas pada korelogram unit root test adalah 0,0000, hal ini menunjukkan bahwa model data pada $1^{\text {st }}$ difference ini dapat dimodelkan menggunakan ARIMA.

Alternatif model ARIMA yang dianalisis adalah $\operatorname{ARIMA}(1,1,1), \quad \operatorname{ARIMA}(1,1,3)$, $\operatorname{ARIMA}(3,1,1)$ dan ARIMA(3,1,3). Untuk memilih model ARIMA terbaik, dilakukan pemilihan berdasar nilai probabilitasnya pada setiap 
variabel. Apabila nilainya mendekati 0.00 atau

Tabel 7.Model ARIMA $(1,1,1)$

$\begin{array}{lllll}\text { kurang dari } 0,95 . \text { Penentuan model ARIMA Variabel } & \text { Koefisian } & \begin{array}{l}\text { Standar } \\ \text { Eror }\end{array} & \begin{array}{l}\text { t- } \\ \text { statistic }\end{array} & \text { Probabilitas } \\ \text { terbaik adalah dengan cara memilih yang nilai } & 0.118390 & 0.733434 & 0.161419 & 0.8719 \\ \text { AIC nya terkecil. Model yang bagus adalah :Nilai C } & 0.446640 & 0.201054 & 2.221488 & 0.0269 \\ \text { Schwarz (SIC) criterion kecil, Akaike Information AR(1) } & -0.234371 & 0.218183 & -1.074195 & 0.2835 \\ \text { criterion (AIC) kecil, Sum Squre of errors (SSE) MA(1) } & & \end{array}$

kecil, dan Adjusted R squared besar.

Tabel 6. Unit Root Test D(PRICE)

\begin{tabular}{|c|c|c|c|c|c|c|}
\hline $\begin{array}{c}\text { Auto } \\
\text { correlation }\end{array}$ & $\begin{array}{c}\text { Partial } \\
\text { Correlation }\end{array}$ & & $A C$ & PAC & Q-Stat & Prob \\
\hline$. .^{* *} \mid$ & $.\left.\right|^{* *} \quad \mid$ & 1 & 0.224 & 0.224 & 18.290 & 0.000 \\
\hline$. I^{*} \quad \mid$ &.$|. \quad|$ & 2 & 0.093 & 0.045 & 21.471 & 0.000 \\
\hline.$|. \quad|$ &. $\mid . \quad 1$ & 3 & 0.068 & 0.040 & 23.161 & 0.000 \\
\hline.$|. \quad|$ &.$|. \quad|$ & 4 & 0.020 & -0.007 & 23.314 & 0.000 \\
\hline${ }^{*}|. \quad|$ & ${ }^{*}|. \quad|$ & 5 & -0.066 & -0.079 & 24.903 & 0.000 \\
\hline${ }^{*}|. \quad|$ & *|. | & 6 & -0.122 & -0.101 & 30.361 & 0.000 \\
\hline.$|. \quad|$ & .|. $\quad 1$ & 7 & -0.034 & 0.021 & 30.794 & 0.000 \\
\hline.$|. \quad|$ & $.1 . \quad 1$ & 8 & -0.065 & -0.044 & 32.371 & 0.000 \\
\hline.$|. \quad|$ & .|. $\quad 1$ & 9 & -0.060 & -0.025 & 33.711 & 0.000 \\
\hline.$|. \quad|$ & .1. $\quad 1$ & 10 & -0.019 & 0.005 & 33.842 & 0.000 \\
\hline$. I^{*} \quad \mid$ & $. l^{*} \quad \mid$ & 11 & 0.078 & 0.083 & 36.111 & 0.000 \\
\hline.$|. \quad|$ & ${ }^{*}|. \quad|$ & 12 & -0.058 & -0.104 & 37.375 & 0.000 \\
\hline${ }^{*}|. \quad|$ & ${ }^{*}|. \quad|$ & 13 & -0.094 & -0.082 & 40.672 & 0.000 \\
\hline${ }^{*}|. \quad|$ & ${ }^{*}|. \quad|$ & 14 & -0.131 & -0.120 & 47.095 & 0.000 \\
\hline.$|. \quad|$ & $. l^{*} \quad \mid$ & 15 & 0.044 & 0.112 & 47.834 & 0.000 \\
\hline$. l^{*} \quad \mid$ & $.1^{*} \quad \mid$ & 16 & 0.128 & 0.149 & 54.055 & 0.000 \\
\hline.$|. \quad|$ & $.1 . \quad 1$ & 17 & 0.050 & 0.015 & 55.008 & 0.000 \\
\hline.$|. \quad|$ & $.1 . \quad 1$ & 18 & 0.015 & -0.060 & 55.089 & 0.000 \\
\hline.$|. \quad|$ &. $\mid 1$ & 19 & 0.065 & 0.023 & 56.686 & 0.000 \\
\hline. $\mid . \quad 1$ & .|. $\quad 1$ & 20 & 0.030 & -0.015 & 57.034 & 0.000 \\
\hline.$|. \quad|$ & $.1 . \quad 1$ & 21 & -0.004 & 0.008 & 57.039 & 0.000 \\
\hline.$|. \quad|$ & .1. $\quad 1$ & 22 & 0.034 & 0.039 & 57.495 & 0.000 \\
\hline.$|. \quad|$ & .1. 1 & 23 & -0.041 & -0.045 & 58.138 & 0.000 \\
\hline${ }^{*}|. \quad|$ & ${ }^{*}|. \quad|$ & 24 & -0.136 & -0.110 & 65.303 & 0.000 \\
\hline${ }^{*}|. \quad|$ & .|. $\quad 1$ & 25 & -0.070 & 0.018 & 67.227 & 0.000 \\
\hline${ }^{*}|. \quad|$ & ${ }^{*}|. \quad|$ & 26 & -0.079 & -0.095 & 69.641 & 0.000 \\
\hline.$|. \quad|$ & $.1 . \quad 1$ & 27 & -0.008 & 0.013 & 69.666 & 0.000 \\
\hline.$|. \quad|$ & $.1 . \quad 1$ & 28 & -0.019 & 0.015 & 69.803 & 0.000 \\
\hline${ }^{*}|. \quad|$ & $.1 . \quad 1$ & 29 & -0.079 & -0.046 & 72.244 & 0.000 \\
\hline${ }^{*}|. \quad|$ & *|. I & 30 & -0.102 & -0.092 & 76.385 & 0.000 \\
\hline $.1 . \quad \mid$ & .|. $\quad 1$ & 31 & -0.028 & -0.004 & 76.689 & 0.000 \\
\hline.$|. \quad|$ & .1. 1 & 32 & 0.048 & 0.027 & 77.586 & 0.000 \\
\hline.$|. \quad|$ & .|. $\quad 1$ & 33 & 0.031 & 0.029 & 77.961 & 0.000 \\
\hline.$|. \quad|$ & .|. $\quad 1$ & 34 & 0.007 & -0.004 & 77.981 & 0.000 \\
\hline.$|. \quad|$ & .1. $\quad 1$ & 35 & 0.037 & 0.014 & 78.535 & 0.000 \\
\hline $.1 . \quad 1$ & $.1 . \quad 1$ & 36 & 0.064 & 0.017 & 80.169 & 0.000 \\
\hline
\end{tabular}

Nilai koefisien tiap variabel dari berbagai model ARIMA dan nilai probabilitas $t$ statistic pada tabel 7 -10. digunakan untuk memilih model yang paling sesuai.
Tabel 8.Model ARIMA $(1,1,3)$

\begin{tabular}{lclll}
\hline Variabel & Koefisian & $\begin{array}{l}\text { Standar } \\
\text { Eror }\end{array}$ & $\begin{array}{l}\text { t- } \\
\text { statistic }\end{array}$ & Probabilitas \\
\hline C & $-0,1305$ & 0,752878 & $-0,1734$ & 0,8624 \\
$\operatorname{AR}(1)$ & 0,2668 & 0,567277 & 0,4704 & 0,6383 \\
$\operatorname{MA}(1)$ & $-0,0572$ & 0,566459 & $-0,1010$ & 0,9196 \\
$\operatorname{MA}(2)$ & 0,0342 & 0,128944 & 0,2655 & 0,7907 \\
$\operatorname{MA}(3)$ & 0,0669 & 0,075737 & 0,8835 & 0,3776 \\
\hline
\end{tabular}

Tabel 9. Model ARIMA $(3,1,1)$

\begin{tabular}{lllll}
\hline Variabel & Koefisian & $\begin{array}{l}\text { Standar } \\
\text { Eror }\end{array}$ & $\begin{array}{l}\text { t- } \\
\text { statistic }\end{array}$ & Probabilitas \\
\hline C & -0.1175 & 0.7504 & -0.1565 & 0.8757 \\
$\operatorname{AR}(1)$ & 0.1674 & 1.3156 & 0.1273 & 0.8988 \\
$\operatorname{AR}(2)$ & 0.0483 & 0.2883 & 0.1675 & 0.8671 \\
$\operatorname{AR}(3)$ & 0.0431 & 0.0802 & 0.5373 & 0.5913 \\
$\operatorname{MA}(1)$ & 0.0449 & 1.3169 & 0.0341 & 0.9728 \\
\hline
\end{tabular}

Tabel 10. Model ARIMA $(3,1,3)$

\begin{tabular}{lllll}
\hline Variabel & Koefisian & $\begin{array}{l}\text { Standar } \\
\text { Eror }\end{array}$ & $\begin{array}{l}\text { t- } \\
\text { statistic }\end{array}$ & Probabilitas \\
\hline C & $-0,1239$ & 0.6502 & -0.1906 & 0.8489 \\
$\operatorname{AR}(1)$ & 0.4196 & 0.1067 & 3.9310 & 0.0001 \\
$\operatorname{AR}(2)$ & 0.3979 & 0.8888 & 4.4767 & 0.0000 \\
$\operatorname{AR}(3)$ & -0.7474 & 0.0871 & -8.5790 & 0.0000 \\
$\operatorname{MA}(1)$ & -0.2652 & 0.1000 & -2.6515 & 0.0084 \\
$\operatorname{MA}(2)$ & -0.3774 & 0.0845 & -4.4649 & 0.0000 \\
$\operatorname{MA}(3)$ & 0.7937 & 0.0780 & 10.167 & 0.0000 \\
\hline
\end{tabular}

Tabel 11. Perbandingan Model ARIMA

\begin{tabular}{ccccc}
\hline $\begin{array}{c}\text { ARIMA } \\
\text { (p,d,q) }\end{array}$ & AIC & SIC & SSE & Adj R $^{\mathbf{2}}$ \\
\hline$(1,1,1)$ & 7.457823 & 7.490274 & 10.03232 & 0.047790 \\
$(1,1,3)$ & 7,464074 & 7,518047 & 10,03624 & 0,044743 \\
$(3,1,1)$ & 7.470772 & 7.524969 & 10.06952 & 0.043366 \\
$(3,1,3)$ & 7,452789 & 7,528665 & 9,952028 & 0,065561 \\
\hline
\end{tabular}

Perbandingan nilai Nilai Schwarz (SIC)criterion, Akaike Information criterion (AIC), sum of squared error, dan Adjusted $R$ squared diantara keempat model tersebut tidak jauh berbeda, meskipun demikian terlihat bahwa nilai AIC, SIC dan SSE terkecil serta adjusted $R$ squared terbesar adalah $\operatorname{ARIMA}(3,1,3)$, sehingga dapat dipilih bahwa ARIMA $(3,1,3)$ adalah yang paling sesuai. Untuk menetukan atau memilih salah satu model terbaik juga lebih berfokus pada nilai probabilitas (p) untuk setiap vaiabel, pada Tabel 8 terlihat bahwa nilai probalbilitas AR dan MA masing masing adalah 0,0000, maka model ARIMA $(3,1,3)$ adalah yang dipilih sebagai model terbaik. 
Untuk melihat kelayakan model ARIMA $(3,1,3)$, maka perlu dilihat korelogramnya (Tabel 12) dan diperhatikan nilai probabilitasnya. Tabel 10 menunjukkan bahawa probabilitas (p) nya 0,0000 dan bentuk korelogramnya sesuai tidak ada residu yang melebihi batas atau garis, maka dapat dinyatakan bahwa model $\operatorname{ARIMA}(3,1,3)$ ini sesuai dan dapat diterapkan untuk memodelkan harga jagung pada pasar internasional. Model ini dapat digunakan oleh pelaku usaha untuk memprediksikan harga jagung dan dapat digunakan oleh pembuat kebijakan untuk mennentukan kebijakan berkaitan perdagangan jagung.

Tabel 12. Korelogram Residu ARIMA(3,1,3)

\begin{tabular}{|c|c|c|c|c|c|c|}
\hline $\begin{array}{l}\text { Auto } \\
\text { correlation }\end{array}$ & $\begin{array}{l}\text { Partial } \\
\text { Correlation }\end{array}$ & & $\mathbf{A C}$ & PAC & Q-Stat & Prob \\
\hline$.\left.\right|^{* *} \mid$ &.$\left.\right|^{* *}$ & 1 & 0.224 & 0.224 & 18.290 & 0.000 \\
\hline$.^{*} \quad \mid$ &. & 2 & 3 & 5 & 71 & 0.000 \\
\hline.$|. \quad|$ &. & 3 & 0.068 & 0.040 & 23.161 & 0.000 \\
\hline $.1 . \quad 1$ &. & 4 & 0.020 & -0.007 & 14 & 0.000 \\
\hline$* \mid$ & $* \mid$ & 5 & -0.066 & -0.079 & 24.903 & 0.000 \\
\hline$*$. & $* \mid$ & 6 & -0.122 & -0.101 & 30.361 & 0.000 \\
\hline. &. & 7 & -0.034 & 0.021 & & 0.000 \\
\hline. &. & 8 & & & & 0.000 \\
\hline .1. & .1 & 9 & & & & 0.000 \\
\hline .1. & .1. & 10 & -0.019 & & & 0.000 \\
\hline$.\left.\right|^{*} \quad \mid$ &.$\left.\right|^{*}$ & 11 & 0.0 & 0. & 11 & 0.000 \\
\hline $.1 . \quad \mid$ & $* \mid$ & 12 & -0.058 & -0.104 & 75 & 0.000 \\
\hline$*$ & $* \mid$ & 13 & -0.094 & -0.082 & 40.672 & 0.000 \\
\hline$*|\quad|$ & $*$ & 14 & -0.131 & -0.120 & 47.095 & 0.000 \\
\hline.$|. \quad|$ &.$\left.\right|^{*}$ & 15 & 0.044 & 0.112 & 34 & 0.000 \\
\hline.$\left.\right|^{*}$ &.$\left.\right|^{*}$ & 16 & 0 & & & 0.000 \\
\hline. $\mid$ &. & 17 & & & & \\
\hline. &. & 18 & & & & 00 \\
\hline .1. & .1. & 19 & 0.0 & & & 0.000 \\
\hline .|. | &. $\mid$. & 20 & 0.030 & -0 & 34 & 0.000 \\
\hline. $\mid$ &. $\mid$ & 21 & -0.004 & 0. & 39 & 0.000 \\
\hline. $\mid$ &. & 22 & 0.034 & 0. & 95 & 0.000 \\
\hline .1. & .1. & 23 & -0.041 & -0.045 & & 0.000 \\
\hline$*|\quad|$ & $* \mid$. & 24 & -0.136 & -0.110 & 03 & 0.000 \\
\hline$*$ &. & 25 & -0.070 & 0.018 & 27 & 0.000 \\
\hline$*$ & $* \mid$ & 26 & -0.079 & -0.095 & 69 & 0.000 \\
\hline. &. & 27 & -0.0 & 0. & 66 & 0.000 \\
\hline. $\mid$ &. & 28 & -0.019 & 0. & 33 & 0.000 \\
\hline$*|\quad|$ & .1 & 29 & -0.079 & -0.046 & 72 & 0.000 \\
\hline$*|\quad|$ & $* \mid$. & 30 & -0.102 & -0.092 & 76.385 & 0.000 \\
\hline.$|. \quad|$ & .1 & 31 & -0.028 & -0.004 & 76.689 & 0.000 \\
\hline $.1 . \quad \mid$ &. & 32 & 0.048 & 0.027 & 77.586 & 0.000 \\
\hline. $\mid 1$ &. & 33 & 0.031 & 0.029 & 77.961 & 0.000 \\
\hline.$|\quad|$ &. & 34 & 0.007 & -0.004 & 77.981 & 0.000 \\
\hline. $\mid$ &. & 35 & 0.037 & 0.014 & 78.535 & 0.000 \\
\hline. &. & 36 & 0.064 & 0.017 & 80.169 & 0.000 \\
\hline
\end{tabular}

Mencermati ordo pada model tersebut, yaitu $(3,1,3)$, maka dapat diinterpretasikan bahwa selisih atau kenaikan dan penurunan harga jagung pada waktu tertentu adalah dipengaruhi oleh selisih harga pada bulan bulan sebelumnya, yaitu selisih pada 1 bulan, 2 bulan, dan 3 bulan sebelumnya. Nilai D(PRICE) hasil hitungan atau simulasi mengunakan model ARIMA $(3,1,3)$ dapat dilihat pada Gambar 3 . Tampak bahwa nilai D(PRICE) menunjukkan kecenderungan stasioner.

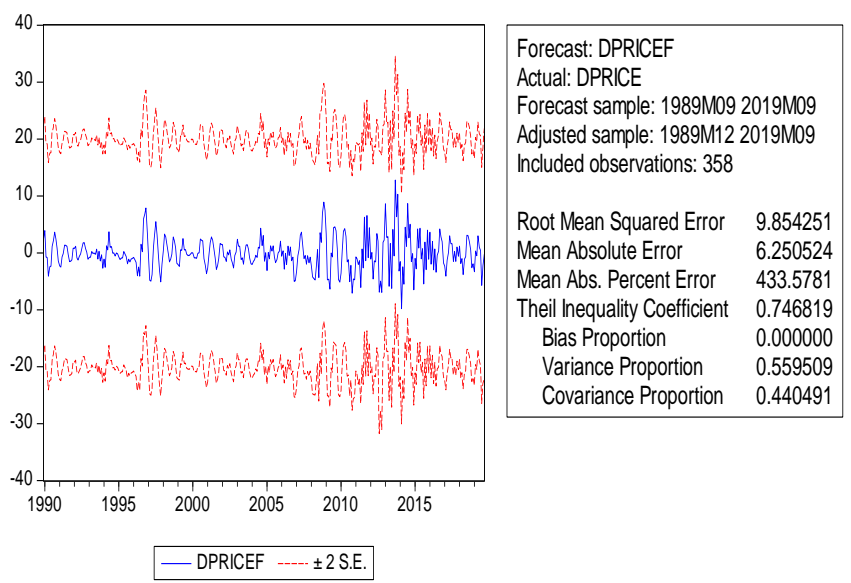

Gambar 3. Grafik D(PRICE) menggunakan model ARIMA $(3,1,3)$

Telah disebutkan di atas bahwa model yang sesuai adalah ARIMA $(3,1,3)$, ordo d adalah 1, dan hal tersebut mengindikasikan bahwa yang variabel yang linear adalah variabel turunan pertama ( $1^{\text {st }}$ difference), atau sering disebut sebagai selisih harga jagung bulan tertentu dengan bulan sebelumnya. Ordo p dan q adalah 3, maka selisih harga jagung dari tiga bulan sebelumnya adalah berpengaruh terhadap selisih harga jagung bulan ini. Kenaikan ataupun penurunan harga dipengaruhi oleh selisih harga tiga bulan sebelumnya. Sehingga untuk forecasting diperlukan data beberapa bulan sebelumnya, lebih dari 3 bulan sebelumnya.

Telah dilakukan peramalan menggunakan ARIMA (3,1,3) untuk peramalan harga jagung beberapa bulan ke depan, untuk permalan dilakukan penambahan data terkini, yaitu harga jagung hingga April 2019, kemudian dilakukan peramalan harga jagung hingga Maret 2021. Pada data Januari 2020 hingga April 2020, terlihat bahwa harga mengalami penurunan, salah satu faktor penyebabnya adalah adanya pandemi COVID -19 yang terjadi secara global, sehinga mengakibatkan perlambatan aktivitas ekonomi dan konsumsi masyarakat. Pandemi global COVID -19 memberikan dampak secara khusus pada produk pertanian dan rantai pasoknya (Ker, et.all, 2020). Pandemi ini dapat meningkatkan tingkat pembelian 
bahan baku makanan pada pasar karena banyak masyarakat yang berbelanja langsung ke pasar dan memasak sendiri, namun menyebabkan tingkat pembelian makanan di rumah makan berkurang, sehingga secara umum menyebabkan tingkat pembelian bahan makanan berkurang (Nicola,et.all,2020). Secara teori disebutkan bahwa pengaruh pandemi terhadap ekonomi adalah tidak linear (Goenka, 2014), sehingga model yang idealnya mendekati linear, ketika terjadi pandemi dapat berubah menjadi tidak linear.

Hasil peramalan (forecast) harga menggunakan model ARIMA $(3,1,3)$ menunjukkan penurunan harga jagung. Secara umum, model $\operatorname{ARIMA}(3,1,3)$ dapat menunjukkan model kecenderungan harga jagung dengan menggunakan data sejak tahun 1989. Namun untuk peramalan harga tahun 2020 dan 2021 ini, hanya akan digunakan data terkini, yaitu data dari Januari 2019 hingga April 2020, untuk mengurangi terjadinya bias yang besar yang disebabkan oleh kejadian kejadian pada jangka pendek.

Tabel 13. Harga Jagung Januari 2019 - April 2020

\begin{tabular}{lc}
\hline \multicolumn{1}{c}{ Bulan, } & Harga (US \$ / Ton) \\
\hline Januari 2019 & 166,74 \\
Februari 2019 & 169,52 \\
Maret 2019 & 166,22 \\
April 2019 & 161,49 \\
Mei 2019 & 171,08 \\
Juni 2019 & 195,08 \\
Juli 2019 & 189,42 \\
Agustus 2019 & 163,59 \\
September 2019 & 157,26 \\
Oktober 2019 & 167,15 \\
November 2019 & 166,33 \\
Desember 2019 & 166,96 \\
Januari 2020 & 171,79 \\
Februari 2020 & 168,71 \\
Maret 2020 & 162,42 \\
April 2020 & 146,91 \\
\hline Sumber data: Indexmundi
\end{tabular}

Sumber data: Indexmundi Maize (corn) Monthly Price, 2019

Tabel 14. Peramalan Harga Jagung Mei 2020 Hingga Maret 2021

\begin{tabular}{lc}
\hline \multicolumn{1}{c}{ Bulan, } & Harga (US \$ / Ton) \\
\hline Mei 2020 & 150,7346 \\
Juni 2020 & 148,0727 \\
Juli 2020 & 146,0917 \\
Agustus 2020 & 144,2385 \\
September 2020 & 142,0317 \\
Oktober 2020 & 139,6439 \\
November 2020 & 137,4044 \\
Desember 2020 & 135,3141 \\
Januari 2021 & 133,1838 \\
Februari 2021 & 130,9556 \\
Maret 2021 & 128,7206 \\
\hline
\end{tabular}

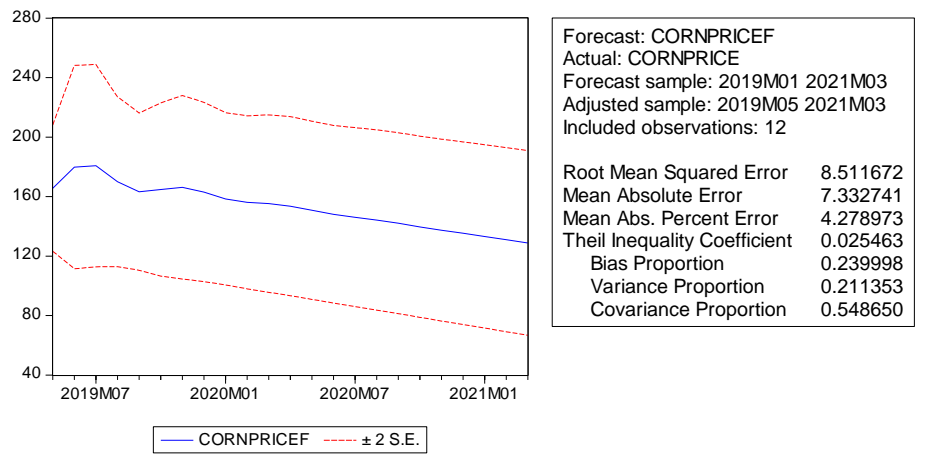

Gambar 4. Grafik Hasil Peramalan Harga Jagung Internasional Hingga Maret 2021

\section{Kesimpulan}

Pemodelan harga jagung dapat dilakukan pada turunan pertama atau selisih harga jagung, karena sifat stasionaritas data terdapat pada selisih harga jagung ( $1^{\text {st }}$ difference $)$ atau variabel D(PRICE), bukan pada harga jagung (PRICE). Model ARIMA yang paling sesuai untuk pemodelan harga jagung adalah ARIMA $(3,1,3)$. Peramalan harga jagung pada tahun 2020 dan 2021 menunjukkan kecenderungan penurunan harga.

\section{Daftar Pustaka}

Arcaz, E.R. dan Wilkinson,M. (1979). Stabilization policies for United States feed grain and livestock markets. Journal of Economic Dynamics and Control, 1(1), 39-58.

Ardiani,N. (2009). Rantai pasokan jagung di daerah sentra produksi Indonesi. Pangan, 53, 7385 .

Bantacut,T. Akbar, M.T. dan Firdaus, Y.R. (2015). Pengembangan jagung untuk ketahanan pangan, industri, dan ekonomi. Pangan, 24(2), 135- 148.

Firdaus,M. (2011) Aplikasi ekonometrika untuk data panel dan time series, PT Penerbit IPB Press Bogor, Indonesia.

Firna, V. (2018). Dampak tarif impor jagung terhadap kesejahteraan pelaku pasar jagung Indonesia. Jurnal Agrosains dan Teknologi, 3(1), 47-64.

Food and Agriculture Organization of the United Nations (FAO), Crops and livestock products, http://www.fao.org/faostat/en/\#data/TP , diakses tanggal 28 April 2020, pukul 10.00.

Goenka, A., Liu,L., Nguyen,M. (2014). Infectious disease and economic growth. Journal of Mathematical Economics, 50, 34-53.

Hyndman,R.J. dan Athanasopoulus,G. (2018), Forecasting: principles and practices, 
Monash University, Australia

https://otexts.org/fpp2/ diakses pada 3

Desember 2018 pukul 8.00.

Indexmundi Maize (corn) Monthly Price - US Dollars per Metric Ton.

https://www.indexmundi.com/commodities/

?commodity $=$ corn $\&$ months $=360$

Diakses pada 10 Oktober 2019 pukul 08.00.

Ker, A.P. dan Cardwell, R. (2020). Introduction to the special issue on COVID-19 and the Canadian agriculture and food sectors: Thoughts from the pandemic onset. Canadian Journal of Agricultural Economics, 1, 1-4.

Kornher, L. dan Kalkuhl,M. (2013). Food price volatility in developing countries and its determinants. Quarterly Journal of International Agriculture, 52, 4, 277-308.

Mengyuan, Q. (2015). “An empirical study on the relationship between corn futures prices of China and the United States", Journal of International Studies, 8(3), 191-200.

Nicola, M., Alsafi, Z., Sohrabi, C., Kerwan, A., AlJabir, A., Iosifidis, C., Agha, M., Agha, R., (2020). The socio-economic implications of the coronavirus and COVID-19 pandemic: a review, International Journal of Surgery, 124 , https://doi.org/10.1016/j.ijsu.2020.04.018 .

Oktiani,D. (2016). Analisis ketersediaan pasokan jagung dari lampung sebagai bahan pakan unggas. Teknologi Agroindustri, 8(2), 1-5.

Pannikai, S.,Nurmalina, R., Mulatsih,S. dan Purwati .(2017). Analisis ketersediaan jagung nasional menuju pencapaian swasembada dengan pendekatan model dinamik. Informatika Pertanian 26(1), 4148.

Purwasih,R. Firdaus, M., Hartoyo, S.(2017). Transmisi harga jagung di Provinsi Lampung., Jurnal Agribisnis Indonesia, 5(1), 75-88.

Pusat Data dan Sistem Informasi Pertanian Kementerian Pertanian Republik Indinesia. (2016). Outlook komoditas pertanian tanaman pangan jagung, Jakarta: Kementerian Pertanian, 2016. Pusat Data dan Sistem Informasi Pertanian Kementerian Pertanian Republik Indinesia.

Pusat Pengkajian Perdagangan Dalam Negeri Badan Pengkajian dan Pengembangan Perdagangan Kementerian Perdagangan Republik Indonesia. (2018). Analisis perkembangan harga pangan pokok di pasar domestik dan internasional, Jakarta: Kementerian Perdagangan, Indonesia.

Rahmah, D.M., Rizal, F., dan Bunyamin, A. (2017). Model dinamis produksi jagung di Indonesia. Jurnal Teknotan, 11(1), 30-40.
Rahmi,E. dan Arif, B. (2012). Analisis transmisi harga jagung sebagai bahan pakan ternak ayam ras di Sumatera Barat . Jurnal Peternakan Indonesia, 14(2), 343-348.

Setiawan,K. dan Basri, M. (2017). An analysis of efficiency the production of commodities corn in Belu, East Nusa Tenggara, Indonesia. IOSR Journal of Environmental Science, Toxicology and Food Technology, 11(10), 64-69.

Susanti, L.S., N. Ali, Ridwan, dan Rohani. (2017). Fluktuasi harga jagung sebagai bahan pakan ternak pada peternakan X di Kecamatan Wonomulyo, Seminar Nasional Peternakan 3 tahun 2017, Universitas Hasanuddin Makasar, 18 September 2017, 217-221.

Susila, U. (2012).Dampak impor dan ekspor jagung terhadap produktivitas jagung di Indonesia, Jurnal Etikonomi, 11(2), 158-179.

Svanidze, M. dan Gotz,L. (2019). Determinants of spatial market efficiency of grain markets in Russia. Food Policy.89, 1-10.

Wright, B.D. (2011). The economics of grain price volatility. Applied Economic Prospectives and Policy, 33(1), 32-58. 